\title{
The Unfinished Business of Erving Goffman: From Marginalization Up Towards the Elusive Center of American Sociology
}

\section{Francesco Ranci ${ }^{1}$ (D)}

Accepted: 12 April 2021 / Published online: 19 May 2021

(C) The Author(s), under exclusive licence to Springer Science+Business Media, LLC, part of Springer Nature 2021

\begin{abstract}
Erving Goffman's written legacy bears on sociology as a whole, or so he argued in his Presidential Address to the American Sociological Association (Goffman, 1983). However, while being celebrated as important to the discipline, his work is also interpreted in inconsistent ways, often downplayed or marginalized, and even neglected. This paper claims that Goffman's "well known aversion to self-disclosure" (Shalin, 2013) does not justify overlooking his trajectory, from the unknown "margins" of a Canadian small town to the elusive "center" of American sociology-and much less does it justify still circulating assessments of his personality, crafted while overlooking his life experiences - and, especially, his writings. Anecdotal evidence of his "enigmatic" personality (Lemert, 2003), or "bad-boy outrageousness" (Berger, 1986), works as a derailing tactic, leading to unwarranted appraisals of Goffman's personality - and, more importantly, to the neglect of crucial aspects of his work. From a theoretical standpoint, Simmel's treatment of "the stranger" as a social relationship, and Merton's concept of "moral alchemy", are used here to try to make some sense of the mixture of celebration and neglect still surrounding "Goffman". Historical data was gathered in part from the "Erving Goffman Archives"' (Shalin, 2013).
\end{abstract}

Keywords Erving Goffman · Interaction Order · History of Sociology · Biography · Microsociology $\cdot$ George Simmel

Francesco Ranci

francescoranci@yahoo.com

1 Member, History of Sociology and Social Thought Section, ASA - American Sociological Association, Washington, D.C., USA 


\section{Introduction. Do "Social Situations" Matter ? Goffman's Celebration and Neglect}

I am assuming, as it was suggested to me for the sake of clarity by Taylor Winfield, ${ }^{1}$ that no reader knows much about Erving Goffman and his work yet. What I take for granted is only that he is regarded as an important and influential sociologist, somehow to be placed at the "center" of the discipline. ${ }^{2}$ But surprisingly he is also altogether absent from a currently used "Sociology 101 " textbook. ${ }^{3}$ And, not less surprisingly considering his worldwide popularity and his often recognized affinities with Durkheim and Simmel, he is also missing from an academic publication concerned about the "identity" of European and American sociology which came out ten years after his death. ${ }^{4}$

As we approach the year 2022, in which he would have turned a hundred year old, some of his pages are being used by American and foreign departments of sociology to demonstrate to their undergraduate students that "sociology" talks about them too. This well established practice goes back to his own lifetime, and reinforces the assumed "goffmanian" influence on sociology over the last half a century. ${ }^{5}$ But Goffman never took into consideration any "quantitative data". Contrary to what mainstream sociologists retain as mandatory today, as undergraduates taking "Sociology 101" are soon bound to discover. Even though it goes without saying that classic sociological work does not heavily rely on "quantitative" methods - Max Weber, for one, pointed to the inconclusive results one can reach, based on statistical data only, in the study of the relationships between religious and economic beliefs (Weber, 1905), introductory sociology textbooks are built around a skeleton of statistical data, and submit the fact that the same statistical evidence can be used in support of contradictory explanations to the choice of a "paradigm" by the sociologist. The given distribution of "median household incomes", for example, is offered either as evidence of the importance of the supposedly more or less valuable "contributions to society" of those earning those incomes, or as evidence of unfair "discrimination" depending upon the student's choice between a "functionalist" or "conflict" standpoint. These alternative explanations raise questions about who decides what jobs

\footnotetext{
1 Winfield recently published a very helpful paper about Emile Durkheim's mindset and religious sources of information and inspiration (Winfield, 2020).

2 Wikipedia, refers to (Fine and Manning, 2003; Winkin, 1988) and several other sources.

3 D. Stanley Eitzen, Kelly Eitzen Smith, and Maxine Baca Zinn, In Conflict and Order: Understanding Society, excludes Goffman in later editions. My perspective is biased by a ten year experience of teaching introductory courses to undergraduate students in the U.S., more often than not having to comply with the mandatory use of a textbook chosen by the department. It is also biased by the fact that, being myself a transfer from Europe (one of the countries nicely included in the "PIGS" acronym), I am not terribly sure of myself when asked to identify the "center" of American sociology.

${ }^{4}$ He would likely be included in it today, but a comparison of American and European sociology published in the aftermath of the collapse of the Soviet Union did not feature his name at all, while mentioning Blumer, Coser, Garfinkel, Goulnder, Homans, Wallerstein, and C.W. Mills, as those who challenged the "structural functionalism" of Parsons and Merton (Nedelmann, 1993:46).

5 The terms like "goffmanian", or "goffmanesque", were coined after him already in his times, and they are still circulating today.
} 
are most valuable to "society as a whole", and of how this structural or systemic inequality is to be squared with the "principle of equality".

Goffman's position, grounded in his mentor's Lloyd Warner's standpoint that it amounts to a self-contradiction to argue that American society is based on the principle of equality "because anyone can climb to the top", of inequality, is that "in almost all contemporary service transactions, a basic understanding seems to prevail: that all candidates for service will be treated 'the same' or 'equally', none being favored or disfavored over the others. One doesn't, of course, need to look to democratic philosophy to account for the institutionalization of this arrangement: all things considered, this ethic provides a very effective formula for the routinization and processing of services". Furthermore, "one can hardly say that some sort of objectively based equal treatment ever occurs, except perhaps where the server is eliminated and a dispensing machine is employed instead. One can only say that participants' settled sense of equal treatment is not disturbed by what occurs, and that of course is quite another matter" (Goffman, 1983). Following Goffman's considerations, in other words, seems to bring one far away from the "center" of mainstream sociology and current social thought. ${ }^{6}$

\section{Goffman's “Qualitative” Standpoint}

Carrying on an established tradition, a recent appraisal of his work (Collins, 2016), while apparently celebrating Goffman's important role in the history of sociology, confines his work inside the vague domain of "microsociology", and considers his position on methodological matters just plainly outdated. In Collins' version, "micro-sociology grew up with a sequence of inventions that might be called information technologies: tape recorders, videos, photos of facial expressions of emotions, long-distance photography, computer-stored messages, and now portable monitors of physiological body signs being used in sports training and the military". Reading this account gives the impression that Goffman was not around, anymore, already "when Sacks, Schegloff and Jefferson in 1974", using taped conversations, "laid out the turn-taking rule as the fundamental process of talk". According to Collins, only after this point in time "it became possible to reinterpret", conversations, "later", to consider them "as the socially ideal form: no gap, no overlap between speakers is talk in maximally attuned rhythm, and it exemplifies high solidarity in that little temporary group", and it became finally possible to understand even that "violating the no gap rule gives embarrassing pauses, micro-indications of what Goffman called alienation from interaction". Collins does not mention at all that

\footnotetext{
${ }^{6}$ It is still routinely argued that the "equality of opportunity" is, or could be, offered to all children without worrying about the "inequality of outcomes" they will reach as parents-and, somehow, while "protecting the family" as well. Ritzer's "The McDonaldization of Society" (1993) can be considered complementary to Goffman's analysis in showing the growing importance of "service transactions" over the last decades. Even though ending up talking about "the irrationalities of rationality", as Ritzer does, has to be "translated" in Goffman's operational definitions, such as those about embarrassing "situational improprieties", in order to integrate Ritzer's and Goffman's results.
} 
Goffman never used taped conversations when he could have done so, for example, in his book Frame Analysis, which was also published in 1974. Collins does not take into consideration any of Goffman's statements, available in several of his writings from 1953 to 1983, about turn-taking as a crucial aspect of conversations, and about the shortcomings of using tape recorders and other information technology devices.

By taking for granted that "progress" is to be measured in terms of "technology", Collins and other critics follow a basic norm of competitive social environments. They define themselves as "relatively worthwhile by emphatically pointing out that certain others are not" (Anderson, 2003:216). And by downplaying Goffman's thoughtful work, they implicitly disparage most of the sociological work, done in the past or even today, without depending on recording devices.

Apparently following what Merton called an "American", as opposed to a "European", tradition of social science (Merton, 1957), the use of quantitative data has become close to mandatory today, notwithstanding Merton's own reflections on this topic which are largely absent, anyways, from current conversations or textbooks. ${ }^{7}$ Goffman, to be sure, endorsed the use of quantitative methods for purposes such as, for example, keeping track of the relationships between growing "ethnic" populations and the appearance of "their own" elected representatives in local governments (Goffman, 1983). ${ }^{8}$ But his choice of pursuing what he called "Simmel's method" (Goffman, 1959) put him in the position of having to defend his own work, against the increasingly mainstream concept, in post-World War Two America, of what "the science of society" was supposedly about. This predicament still bears heavily on social science, including its view of "Goffman". 9

\section{Ash, Milgram, Zimbardo, and Goffman}

Given how Goffman pointed to ethologists and their skillful use of fieldwork methods as an example to be followed by sociologists (Goffman, 1971), he would likely be surprised by the way a neurologist and primatologist with decades of fieldwork experience, in his recent book Behave: The Biology of Humans at Our Best and

\footnotetext{
7 The debate on this issue can't be summarized here. My point is that Goffman's own work falls squarely outside the domain of any "quantitative" methodology whatsoever, thereby offering a model of sociological research which goes de facto against mainstream views. Merton was suggesting a "combination" of the two styles, not the "colonization" of "European" sociology—or as Rizter later called it, the "McDonaldization of Society" (Ritzer, 1993), including sociology worldwide.

${ }^{8}$ Or even for recording a conversation, if one so desires, provided one knows about what gets lost in the process of selecting a given amount of bits of "information" from a social situation, and takes into account that it will remain implicit-if not otherwise introduced-in the analysis of the recording.

9 Goffman makes clear in the Preface to his first and by far most popular book (Goffman, 1956; Goffman, 1959) that he is following Simmel's path to sociological knowledge, with respect to finding the evidence he needs to prove his generalizations. This reference to Simmel can be superficially read as a mere rejection of the "quantitative methods" alternative, and possibly based on this reading it can be ignored, as Collins did, when he argued that "in the 1950s Goffman deserted Freud for Durkheim" (Collins, 2016).
} 
Worst (2017), entrusts so much of his knowledge of society to statistical correlations, largely obtained in laboratory experiments. ${ }^{10}$ Showing how a book should not be judged by its cover, Sapolsky turns to the social sciences, but only to find that "it is virtually required by law to discuss three of the most influential, daring, disturbing, and controversial experiments in the history of psychology: the Ash, Milgram and Zimbardo experiments" (Sapolsky, 2017:461). Of course, most "SOC 101" textbooks are also informed by this "requirement".

After following some of the controversies surrounding these classic experiments of social psychology up until today, Sapolsky asks around, and, repeating "the words of Harvard psychologist Mahzarin Banaji", ${ }^{11}$ claims what we have learned from them is that "situations matter (her emphasis)" (Sapolsky, 2017:464). Banaji's "emphasis"- that situations matter-from a "goffmanian" point of view brings into question the choice of taking those "experimental" situations as paradigms to be applied to everyday social situations. This is indeed the topic-social situations-about which Goffman, possibly more convincingly than anyone else within the sociological tradition, has written about-without resorting to a single laboratory experiment. ${ }^{12}$

Entirely by-passing what Merton called "The Thomas Theorem” (Merton, 1957) and entirely by-passing Goffman's work, including his warning about the wrong interpretation this "theorem" (Goffman, 1974), ${ }^{13}$ Sapolsky concludes that from the Ash experiment "we should learn that, in the name of conformity, average people will go along with absurdly incorrect assertions". Likewise, from "the other two" experiments, we should learn that "average people will do stunningly bad things", in the name of obedience and conformity (Sapolsky, 2017:464). A comparison of these experiments with Goffman's treatment of "total institutions" (Goffman, 1961a), demonstrates how social issues like "conformity and deviance" can be more fruitfully investigated by taking into consideration real prisons, rather than building mock ones and filling them up with one's own college students (male, white, still fresh from their own "hazing" practices, and so on). At the very least, after reading Goffman, one is able to avoid ending up with the alternative of blaming "the barrel", which supposedly made so many apples "go bad", rather than blaming "bad apples", as it is routinely done. Zimbardo's metaphor, a barrel full of apples, may be a useful twist of the traditional metaphor of the "bad seed", but it is not that much more enlightening. More importantly, issues of morality_-"good or bad"—are not where

\footnotetext{
${ }^{10}$ Contrary to "a certain breed of social scientists", Sapolsky argues that you can't understand behaviors like aggression and cooperation "without biology". However, he also argues—notwithstanding his title's reference to "biology" only -, "it is also true that you are just as much up the creek if you rely only on biology" (Sapolsky, 2017:4).

11 Recent issues of "The American Sociological Review" feature a debate about Hardvard's "Implicit Bias Test", deviced by Mahzarin Banaji and others.

12 Goffman mentor William Lloyd Warner took part in Mayo's "Hawthorne studies".

13 The "real consequences" postulated by the theorem, occurring when a social situation is defined, are not necessarily going to be those envisioned by the people who defined that situation, as Merton warned providing the evidence of President Lincoln's clear awareness of the possibility of a "self-defeating" outcome. For example, defining Covid 19 as a "regular flue" not only does not change its effects, but may cause those who have so defined it to experience them.
} 
a laboratory experiment can be decisive unless a "social darwinist" view of human nature, or a more recent "bioethical" version of it, is implicitly bought. ${ }^{14}$ Goffman's "dramaturgical approach" (Goffman, 1959) relies on a metaphor to begin with, rather than to conclude his analysis. As a consequence, by itself it may have a lot more to offer in terms of insights. Putting excessive emphasis on quantitative data instead, prevents sociologists and other social scientists from contributing as much as they could to the analyses of social problems.

Establishing the percentages of people who conform to expectations as a result of different modalities of social interaction ("peer pressure", "authority", or "coercion"), is soon given up by Sapolsky anyways, even though it was the official goal of the three experiments. He embraces instead a vague notion of "average people" even though, as he admits, subjects were all of a certain kind, and those experiments can not be replicated today for "ethical" reasons. Furthermore, Sapolsky's conclusion is apparently at odds with Ash's results-reported by Sapolsky as being "replicated frequently by the cottage industry of research spawned by Ash". Sapolsky reports that "Ash's results" consist of "about a third of the time" conformity, which is not equivalent to "average people". ${ }^{16}$ Contrary to what Sapolsky concludes, the Ash experiment shows that people do not just "go along" with absurdly incorrect assertions. Even though the number of those who do "conform" does turn out to be "higher than what one would expect", that is only if one expects people not to have any tendency to "conform", or to pretend that they do so, when left alone in a laboratory full of strangers acting quite "crazy". 17

In other words, Sapolsky's claim fall in the domain of the incorrect interpretation of "The Thomas Theorem": the "real consequences", postulated by the theorem as occurring once a social situation is defined, are not necessarily going to be those envisioned by the people who define "the situation" as real. ${ }^{18}$ The supposed result of Ash's experiment—only "about one third conformity" —is, for what it is, more in line with

\footnotetext{
${ }^{14}$ Unless, that is, one is committed to entrust one's own moral judgements to the result of a laboratory experiment, which is a standpoint of sorts, but quite dismissive of one's own duty to take responsibility for one's own choices. Goffman's position on "human nature" was certainly a different one (Goffman, 1955).

15 A concept that Goffman does not use, not only because it depends on a quantitative estimate, but also because "situations matter".

${ }^{16}$ Since the answers to Ash's test can only be either correct or incorrect, there is no possibility of an "average" response. The only approximation to an "average value" one can think of, a value that allows a somewhat reliable prediction of what the response the next subject of the experiment will be, requires some degree of prevalence.

17 The Ash experiment requires an isolated subject to deny an undeniable evidence, concerning the respective length of three lines, "in the name of conformity" to the wrong evaluation previously offered by a number of "Ash's confederates".

${ }^{18}$ Believing in "white supremacy" has real consequences, but not necessarily those envisioned by those who believe in "white supremacy". For example, historians are still debating what Rudolph Hess was doing, secretly flying to Scotland in 1941. Possibly, Adolf Hitler did not expect England to really wage war against Germany, but instead to acknowledge their belonging to the "white race". As Goffman writes, "Thomas dictum (...) is true as it reads but false as it is taken", because "defining situations as real certainly has consequences, but these may contribute very marginally to the events in progress" (Goffman, 1974:1).
} 
Goffman's notion of a "working consensus" (Goffman, 1951), quickly reached by participants by taking into consideration several factors, and always at risk of being "discredited" by evidence deemed relevant to the definition of the situation-even when one is surrounded by Ash's confederates doing their best to deny such evidence.

Percentages are higher in "the other two experiments", which introduce a more explicit power relationship in the laboratory. What Goffman writes about power is not surprisingly relevant here as well. While offering his own criteria for assessing the likelihood of what he called "flooding out behaviors", Goffman argues that it is "no accident" the fable of the invisible new clothes "concerns and emperor". 19 The "image", as he calls it-meaning the metaphoric use of the words "flooding out" -, seems to him "hydraulic, and not entirely adequate". The words "flooding out" suggest that, as the "tension level" increases, so will the likelihood of reaching the "breaking point" after which the "flooding" occurs. Common-sense use of this metaphor neglects, Goffman points out, "some important social determinants of how much tension can be withstood before a flooding out occurs". Clearly, his argument runs, "so much difficult disregard for nakedness could hardly be sustained in any case, including that of a less consequential figure". ${ }^{20}$ In other words, the tale would work just fine with any idiot: it does not seem to require an emperor. But it is instead necessary to have an emperor in the fable because - as a sociological point of view allows one to understand -, it is "during occasions when the reputation of large organizations or high persons are at stake that any open admission that things are not what they seem will carry externally relevant consequences that no one wants to face". Here Goffman's sarcastic touch comes alive: it is on those occasions that "a great deal of tension may be doggedly contained" 21 so that more people decide to go along with the experiment, or pretend that they do so, when a power relationship is emphasized by the definition of the situation. ${ }^{22}$

Goffman's sociological considerations about "large organizations", "high persons", "reputations", "externally relevant consequences", and "doggedly behavior", do beg the question of how the "containment" ultimately depends on the "child". It can be hardly considered an "accident" that the fable also features a child among its two main characters. One has to allow that at times the "externally relevant consequences that no one wants to face", as Goffman describes them, are actually faced and challenged. Or, in Goffman's words, "under certain circumstances the individual may allow his manners to be inundated by a flow of affect that he no longer makes a show of concealing". As Banaji's and Sapolsky say, "situations matter", and Goffman's work is focused on how what he calls the "interaction order" is sustained or not, in different circumstances, by the people involved in it. Goffman does not neglect

\footnotetext{
19 Goffman takes it for granted that everyone knows the basic narrative of this tale, first published in 1837 by Hans Christian Andersen as the final item of his collection of traditional Danish populare tales under the title "Fairy Tales Told for Children".

${ }^{20}$ His words were written for a time, and place, when disregard for nakedness was probably more difficult to sustain than it is today.

21 Goffman (1961b, Dynamic of Encounters, 5. Flooding Out).

22 As it happens with "the other two" experiments.
} 
power relationships, as some critics occasionally claim. While he is not interested in singing "a lullaby" neither is he, as he wrote, busy "waking up" people to their own supposed "real interests", arguing that their "sleep is very deep" (Goffman, 1974). Criticising James, Schutz, Garfinkel, and others, ${ }^{23}$ he points out that, even for the sociologist, to speak of "everyday life" as if it were "the world of wide-awake practical realities" is "merely to take a shot in the dark" (Goffman, 1974:26). In his address to the American Sociological Association, he argues that the two reasons sociologists should apply "the spirit" of the natural sciences to social life are that "it is ours", and that it "is there". It's not because we might want to change it for the better, although, when he says that it is "ours", that might be implied. His position has been criticized, as a consequence, for being politically "conservative" (Gouldner, 1970) which might explain, in part, the lack of appreciation for his work by "engaged sociologists". The real "political" question for Goffman is that concerning the use, or the abuse, of "quantitative" methods. ${ }^{24}$

Besides the lack of consideration for their own methodological rules showed by some "quantitative" studies-for example, when they apparently disregard the crucial distinction between "correlation" and "causation" (Sutherland, 1940), and besides other arguments Goffman repeatedly made in defense of his choice of personally staying away from any kind of "quantitative" methodology (Goffman, 1964), his position is not to be considered, as Collins does, outdated. Nor can it be considered "isolated" within sociology. Within the "qualitative" standpoint is Becker's argument, for example, that an unwarranted assumption of synchronicity, that all events supposed to determine one's addiction - for example - to a given drug must happen at the same time, is implicit when factor analysis is applied to social phenomena (Becker, 1963). Biologist and social commentator Stephen J. Gould (Gould, 1981) added to Becker's argument that statisticians are also assuming a consistency of all the phenomena described by the measurements involved - a consistency which, as Merton pointed out long ago, can only be a matter of investigation is social science (Merton, 1957). ${ }^{25}$ The target of Gould's criticism was the "psychology" used to give meaning to the category of "intelligence" at the turn of the XXth Century, but with his methodological warning he deliberately called into question much more recent studies just as well (Gould, 1993). Claims of "superior" intelligence based on "intelligence tests", Gould shows, replaced Morton's "craniometry" and other absurdities as the basic staple of "scientific" racism, and their legacy can still be seen today when a

\footnotetext{
23 This criticism may also involve his students Berger and Luckmann (1966). Berger's recollection is that a statement by Schutz, during one of his lectures, was inspirational: Schutz allegedly declared that "the sociology of knowledge must study everything that passes for knowledge in society".

24 He defines the problem as "political" in his interview with Verhoeven (Verhoeven, 1993).

25 The "consistency" and the "sinchronicity" postulates do make sense within developmental biology because many different parts of an organism will grow at similar rates, thereby allowing the biologist to identify a given "stage of development" by using a few measurements - and then quite safely predict the results of other possible measurements, of the same organism, instead of having to actually take those other measurements, which is obviously a time-consuming activity. However, such postulates become unreliable when dealing with surveys and "experiments" with human behavior.
} 
conservative presidential candidate boasts his own "much higher IQ", just as much as when an outstanding (liberal) scientist argues that conservatives have a "lower IQ" than liberals (Sapolsky, 2017), or when a (liberal) President of the United States calls his (conservative) opponents "Neanderthals".

\section{Goffman's “New Way to Study Mental Illness": Questioning the Concept}

Goffman's concern about psychiatric practices and theories is prominent and consistent throughout his scholarly life. An example is a piece of news he uses as "data", reporting that a psychiatrist was brought to court in Los Angeles for having prescribed having sex with him to a patient, and having charged her $\$ 225$ for his "therapeutic intervention". The invoice was what ultimately convinced her to put an end to his behavior and sue him. Goffman argues that "a line should be drawn here" (Goffman, 1974:Ch.5) between unwanted medical attention and the fraudulent use of medical credentials. He points out that popular opinion was so favorable to the concept of "sexual freedom", at the time of his writing, that the psychiatrist's current best-seller on this topic was advocating for the use of such "therapy". Children playing "doctor", is Goffman's sarcastic take on this behavior: they may show a lack of medical knowledge, but they are old enough already to prove themselves "competent users of frames" (Goffman, 1974). ${ }^{26}$ Goffman's irony, at least in this case, contrary to what Charles Lemert argued later (Lemert, 2003) does not make his point any less clear, and implicitly asks to be taken very seriously. Ellen Willis' review of The Love Treatment. Sexual Intimacy Between Patients and Psychotherapists (1972), the best-seller criticized by Goffman for failing to draw the line between unwanted medical attention and "the fraudulent use" of medical credentials, reports that its main premise is that the original prohibition of sexual intercourse between therapist and patient "was broken all the time anyways". After submitting her rhetorical question, "psychotherapy, as conventionally practiced, has proved a useful tool for exploiting women, and so has the ideology of sexual revolution-why not combine them ?", Willis points out that the issue here is "not sex", but "what therapy means, and how it is to be practiced". ${ }^{27}$ Her point is the same as Goffman's point.

At the end of the day, notwithstanding the apparently established consensus about its importance, Goffman's sociology does not square much with current mainstream views. As a result, his work may easily be found to be mischaracterized. In his above mentioned article What Has Micro-Sociology Accomplished (2016), Collins argued that Goffman "devised a new way to study mental illness: he got himself into the schizophrenic ward of a mental hospital, incognito, for two years". The reference here is Goffman's book Asylums: Essays on the Social Situation of Mental Patients and Other Inmates (1961), based in part on fieldwork he conducted in a mental hospital. ${ }^{28}$ Collins

\footnotetext{
${ }^{26}$ Footnote \# 5 of chapter 6.

27 Willis, E., "The Search of the Perfect Lover", The New York Review of Books, August 1972.

28 An unusual but not unprecedented choice of setting for an inquiry like Goffman's (for example, journalist Nellie Bly entered an asylum disguising herself as a patient and published a book about what she experienced ther in 1887).
} 
describes Goffman as an "ardent Freudian" at this point. And it is a vague description which supports the idea of someone who was eager to "observe what mental illness is in the present, as disturbed social interaction”. But Goffman's writings do not offer support to this idea ${ }^{29}$

Goffman argued that "functional" mental illness was distinguished from the traditional notion of "organic" mental illness by Freudian psychiatry, and should not be identified with "disturbed social interaction", as those psychiatrists did. He opposed identifying "symptoms" with "situational improprieties" (what Collins calls "disturbed social interaction", Goffman calls "situational improprieties"). Such "improprieties" should be understood for what they are, and not confused with supposed "symptoms" of an unlikely pathological condition.

As Banaji explained to Sapolsky, "situations matter", but that means, to Goffman at least, that they should be taken into due consideration when assessing someone's behavior. They are instead being neglected by quantitatively oriented approaches (Goffman, 1964). What Goffman argues can be considered "devising a new way to study mental illness", as Collins does, only to the extent that besides exposing the shortcomings of the current way, he puts forward a different one, in part of his own device. But Goffman's analysis is an assessment of a social situation which is basically the same as that of the "other inmates" he mentions in the title of his book (Goffman, 1961a). ${ }^{30}$

\section{An “American” Academic Star}

As we have seen, several reasons can be given for taking the assumed "centrality" of Goffman's work in contemporary sociology with "a grain of salt". It can be assumed, given his Presidency of the American Sociological Association, but only while taking into consideration the elusive character of the "centre" of the discipline. Furthermore, when it comes to "American" sociology, another problem has to be taken into consideration. An anonymous reviewer objected to the first version of this paper that 'it's not correct that Goffman 'later in life became an American'-he never obtained a U.S citizenship, preferring to remain a Canadian national”. My first

\footnotetext{
29 Taking into consideration the adjective, "ardent", it may be considered a dismissive, and even offensive, label. Interestingly enough, Collins goes from complete neglect of Freud's work and of its influence on sociological theory (Collins, 1988), except an occasional use of the adjective "Freudian", all the way to defining him as "Conquistador of the Irrational", summarizing his life and work, finding it "complementary" to Durkheim's and Weber's work, and linking Goffman's "most recent breakthrough" of sociology to Freud's insights (Collins and Makowsky, 1998/1972). However, he also claims that "in the 1950s Goffman deserted Freud for Durkheim" (Collins, 2016). It is outside the range of this paper to properly summarize Collins' position. All that matters here is that the words "ardent Freudian", whether meant favorably or unfavorably, pigeonhole the author in "support", so to speak, of an unwarranted reading of his writings (Goffman, 1981).

30 This point can be further clarified by taking into consideration Hughes letter to Goffman, and his reply, after the publication Asylums (November 1961), which are available on the online "Erving Goffman Archive"'s website. My point is obviously to establish if Goffman can be seen as an "ardent Freudian" or not, even just at this point in his life, not to argue in this paper that Goffman was necessarily "right", or "wrong", which depends on a standard of evaluation.
} 
response to this remark is that Goffman was selected by the American Academy of Arts and Sciences (Amacad), where foreign nationals are included only as "Honorary Foreign Member". A "Member" of Amacad can be either "a citizen or a resident", in both cases qualifying "American" as this institution, which is older than the Star-Spangled Banner.

My second response, less important but possibly more interesting, is that according to at least one credible source Goffman actually signed a sworn statement declaring himself to be "a citizen of the United States". ${ }^{31}$ This signature is part of the incorporation papers of the American Association for the Abolition of Involuntary Mental Hospitalization (AAAIMH), established in 1970. While often neglected, the historical reality of this association has never been questioned-and, on a side note, the abolition of involuntary psychiatric treatments is possibly the only policy position Goffman ever supported in his writings, even though it did not attract much attention from his critics (whether supposedly "value free", or "engaged" sociologists).

I did not use the word "citizenship" in the first version of my paper because I knew of this consensus, likely to be based on hearsay. However, I did not expect a pushback on the notion that "later in life Goffman became an American". In any case, the clarification of this point might turn out to be a small contribution this paper makes to the history of American sociology, and may reveal a deeper than expected undercurrent of uneasiness towards him, and towards "foreign nationals" in general.

Goffman did become a U.S. citizen, probably, but even some of his closest colleagues assumed that he never did, ${ }^{32}$ which can be considered an example of how the "stranger", as defined by Simmel in terms of a social relationship, works.

It is quite unlikely that he did not become a citizen considering that it was not necessary for him to claim U.S. citizenship in order to participate in the founding of that incorporated association. ${ }^{33}$ On the other hand, if he actually "never obtained a U.S. citizenship", as the anonymous reviewer objected, it would turn out that Goffman himself, or his associates, did not "behave as good citizens", contrary to what everyone thought they knew about them-a piece of news which, if true, might be worth a targeted investigation.

\section{Goffman's “Non-Existent Self-Portrait": How Can It Be Explained?}

I argued so far that while being celebrated as important to the discipline, Goffman's work is also at times interpreted in superficial ways, and even neglected in its actual content. Goffman's “well known aversion to self-disclosure” (Shalin, 2013), does

\footnotetext{
${ }^{31}$ My source is "The Thomas S. Szasz Cybercenter for Liberty and Responsibility"'s website.

${ }^{32}$ Dmitri Shalin's interview with Renée C. Fox (https://cdclv.unlv.edu/archives/interactionism/goffman/ fox_08.html).

${ }^{33}$ All other founding members were American citizens, and a minority of non citizens was allowed by the law at the time, as it is now.
} 
not justify neglecting his remarkable trajectory, from a Canadian small town to the elusive "center" of American sociology, and much less does it justify assessments of his personality and convictions that are crafted overlooking his life experiences and his writings. He might have been an "ardent Freudian" in some sense, but not that described by Collins (Collins, 2016).

Putting together the remarkable body of work Goffman produced with his reluctance to enter the public eye, and to become even more of a celebrity than he eventually became, we already get an idea of where his well known "averse to self disclosure" (Shalin, 2013) standpoint may have come from. Not only was his wish for his life and persona not to be fed to public opinion, and much less investigated by anyone, either himself or future scholars. He was not even that interested in debating his views with his colleagues. He believed that neither knowing him as a person, nor listening to him defending his views, would have provided any shortcuts to the understanding of what he was interested in. And much less of what he had to say about it. As he argued in his only reply to his critics, it is the piece of work, having a "life of its own", that one needs to pay attention to: not the biography, or the presumed loyalty to a "paradigm", of its author (Goffman, 1981).

This attitude has given some room to the argument of his alleged inconsistency, and to the idea that he was "hiding" himself, or had something to hide. However, there are likely to be several reasons for Goffman's decision, for example, not to appear on the mass media of the time-newspapers, radio, and television -, as he could have done. One of them could be that he wanted to protect his personal life, as he explains in Stigma when he talks about "fame", and the always unfair praising and blaming it brings with it (Goffman, 1963). ${ }^{34}$ Another possible reason is that, as he stated in his 1981 reply to his critics, he did not want to cast any shadow on his written work.

Probably known to him, and in some way inspirational to his choice, was "modernist" visual artist Gustav Klimt, who refrained from engaging in theoretical debates about his own art in order to avoid casting himself any shadows on his work, or allow others to cast a shadow on it. In his Commentary On a Non-Existent SelfPortrait, the already famous fin-de-siècle Viennese painter explained that "there is nothing special about me. I am a painter who paints day after day from morning to night (...) whoever wants to know something about me-as an artist, the only notable thing-ought to look carefully at my pictures and try to see in them what I am, what I want to do" (Whitford, 1990:18).

Besides refusing to engage in the game of exposing one's supposed private life to public opinion, and of sharing the arena of political or scholarly debates with other public intellectuals, with his paintings Klimt outraged the intellectuals of his time and place, which finds a parallel when one reads Goffman's writings. For example, Klimt worked on the same back then forbidden themes of sexuality explored in those years, also in Vienna, and also in terms of "symbolism", by Freud, who's

\footnotetext{
34 A lot more can be taken from Goffman's writings and used to explain his own self-management. This paper is only a fragment of a larger project I am currently undertaking, provisionally called The Unfettered and Unsponsored Sociologist. Notes on the Mismanagement of Erving Goffman Identity.
} 
"psychoanalysis" was influential on Goffman. While respecting Freud's work, as we have seen Goffman mounted a merciless criticism of psychiatric institutions and of mainstream psychotherapy (Goffman, 1961a).

A voracious reader, Goffman was always "absorbing" information from a vast array of different sources, and Klimt's position is not to be considered an isolated one, but is rather expressing a shared view among many intellectuals. Novelist Arthur Koestler, for example, is said to have sarcastically stated that "to want to meet an author because you like his books is as ridiculous as wanting to meet the goose because you like pate de foie gras." Goffman's rebuttal to Fine's proposal of doing an ethnographic study of his own forthcoming marriage, reportedly "only a schmuck studies his own life"' (Fine, 2009), is another version of this humbling argument.

The rhetorical device allegedly used here by Koestler also helps understand Goffman's style, who makes use of irony and sarcasm in such a consistent way that his work is comparable to only a few other social scientists. One of them is Veblen, whose life experiences and views were in part similar to Goffman's, and whose work clearly influenced his first publication, Symbols of Class Status (1951). ${ }^{35}$

In a Kafkaesque manner, Koestler's novel Darkness at Noon (1940) tells the story of a Soviet revolutionary, who is arrested and tried for treason. But it is the same Soviet regime he helped establish which does that to him. According to George Orwell's review, this novel is "a piece of brilliant literature", and Orwell's own first novel Animal Farm (1945) is also inspired by the issue of betrayal, which was brought about by Orwell's direct experience of communists' violence against "comrades" like him, who were fighting the Spanish Civil War of 1936, supposedly, on the same side of the Soviet Union. ${ }^{36}$ Orwell's novel 1984 (Orwell, 1949) further developed Koestler's theme: the totalitarian regime here even stages a fake revolutionary organization, which captures discontented individuals and delivers them to the establishments as traitors. They are tortured, but not killed, as the totalitarian government operates under the assumption that brainwashing rebels is the most effective way to eliminate them. Goffman, a voracious reader, raised by a family in which theater was the major focus of shared attention, often makes use of literary texts in his essays, and explicitly acknowledges his debt to Orwell in his Reply to Denzin and Keller. ${ }^{37}$

The basic plot of Goffman's On Cooling the Mark Out (1952), later developed in Asylums (1961), is about the social function of the "psychologist", and about the way an individual is fooled, exploited, and then convinced to be at fault himself, for his own "failure", or-in other words_-"brainwashed". As it turns out, the "con game" the individual was initially "recruited" to play was rigged as he was told, but contrary to what he was told, "not in his favor". The "philosophy of taking a loss"

\footnotetext{
35 As demonstrated by Shalin by comparing it to an earlier and unpublished version (Shalin, 2013).

36 And, of course, by the assassination of Leon Trotsky ordered by his "comrade" Stalin in 1940.

37 "I think Roland Barthes is a great pleasure to read, I draw my orientation to the study of fictive materials from Berelson's course on content analysis (some few years ago), and the English-language initiators of the study of popular culture, namely, George Orwell and Dwight Macdonald" (Goffman, 1981:62). Goffman's 1953 Ph.D. dissertation features in its bibliography Orwell's autobiographical essay Shooting an Elephant (1936). Quotations of Orwell are found in Asylums and other books by Goffman.
} 
Goffman sees as a necessary feature of an exploitative society: "cooling the mark out", or calling the psychiatrist, may become necessary to keep "the peace". However, Goffman is far from personally endorsing the "philosophy of taking a loss" embedded in the "anglosaxon middle-class lifestyle" he describes, or in any other shape or form (Goffman, 1971).

Skeptical as he was about what the social world had in store from him, Goffman nonetheless accepted the nomination to become President of the American Sociological Association in 1982, a position which implied a certain amount of disclosure. His presidential address may be considered the best we have, in terms of his own self-portrait, but not much attention has been paid to it. Its first lines introduce an ironic remark addressed to people occupying positions of power, by using the metaphor of the "annual breather", offered to the editor of the American Sociological Review by the ceremonial publication of the presidential address itself. "Once a year-says Goffman - the lead space can be allocated to a known name", and the editor "is quit of responsibility for standards that submissions rarely sustain" (Goffman, 1983).

Fundamental disagreements about both Goffman's work and how it relates to sociology are still circulating while scant information is available with respect to how the relationship between the former and the latter developed historically. In 2022, the first complete biography of Erving Goffman (1922-1982) might finally be published by Greg Smith and Yves Winkin, who have been working on it since the 1980s and have already authored some of the most detailed biographical and critical studies about his intellectual trajectory. In the meantime, almost four decades after his death, the remarkable number of citations, and other uses of his writings within and outside academic sociology does not seem to be declining. ${ }^{38}$

So far, several biographical essays have been published, in part based on archive searches, and an enormous body of scholarship about his writings has been produced. Dmitri Shalin, bypassing and counteracting the impression management strategy followed by Goffman himself, interviewed many people who knew him personally, gathered crucial documents such as unpublished writings, and published his results online at the "Erving Goffman Archives" (Shalin, 2013).

In terms of his social positions, Erving Goffman was born the youngest child and something could be argued already in light of this early "piece of the puzzle". The likely effects of birth order on personality have been investigated for almost a century now. Sulloway found supporting evidence for his "born to rebel hypothesis" by looking at lives like that of Voltaire and at the higher than average participation in scientific and political revolutions of younger siblings (Sulloway, 1996). Observations fitting Sulloway's theory were made by people who knew Goffman personally. For example, Bennet Berger pointed out that "his preoccupations are with what anyone can see, but usually doesn't, unless he looks carefully and with fresh eyes"

\footnotetext{
${ }_{38}$ Google Scholar does not really offer very precise and specific data. However, Goffman's profile in terms of his publications seems to be at least comparable to the numbers reached by acknowledged "founders" of the discipline like Durkheim, Weber, or Parsons. He is way above them considering that he has more publications in the high range of citations.
} 
(Berger, 1973). Berger's is a perfect description of how the youngest member of a family sees their world. However, he was describing a recurrent biographical feature, which by itself can hardly explain much about any single individual. A similar cautionary remark is kept in mind by Shalin and others who are looking for evidence of their "biocritical" explanations in Goffman's writings-for example, his own likely concern about being "short" can be related to how on occasions he discusses this issue in his writings, even though without mentioning himself (Shalin, 2013).

Goffman was also what sociologists in his times called a "second generation immigrant". Someone born in a social world quite different from that of her parents, and often unwelcoming to people who, because of their family situation, are seen as "not really belonging" to the country in which they are born. Or to their parents's country of origin, if they ever happen to go there (Park, 1950:248).

The country where he was born, Canada, was at the time far from what a "nation state", in traditional European terms, is supposed to be. It was part of the weakened, but still mighty British Empire, and in part also a former French colony. This set of circumstances relates to Goffman's sociological view, that of an Eastern EuropeanCanadian citizen, who only later in life became an American. His detachment from the original sociological analysis of social life, based on the context of a centuries old "nation state" undergoing bloody revolutions, like France was for Comte and then for Durkheim, relates to his biographical identity. Even the context of a new world powerhouse like Germany was for Tonnies, Weber and Simmel, does not compare to what Canada ever was.

24Goffman's parents, Ann Auerbach and Max Goffman, met in Winnipeg which was already back then an important commercial and industrializing urban conglomerate, close to Minnesota's border. Both arrived there a few years before the First World War from the Russian Empire, which makes it appropriate to call them "Russians" as Shalin does (Shalin, 2013). However, current tensions between Ukraine and Russia remind us of his father's oppressed national identity, and the same can be said of his mother's with respect to Belarus.

Another relevant background of both migrations, and of the marriage of his parents, is the massive flight of Eastern European and Russian Jews from the dangers caused to them by surges of violent "antisemitism". Canada was not a destination of choice, but rather one of the few, or even the only one, left available to them, as European and American borders had been closed.

The Auerbach family already had several members living in Winnipeg (Cavan, 2014). However, soon after Anne and Max got married they moved 700 miles further West, taking advantage of the brand new railway line, built to develop their new country. The small town they went to was called Mannville after Sir Mann, the businessman who had been put in charge of building the railway itself. There were probably ambitious plans to further development which never materialized.

Goffman's older sister Frances was born in Mannville in 1919. In the meantime the First World War war had brought about the Soviet Revolution, the crisis of European powerhouses, and the rise of the United States to leadership in world politics under President Wilson. The world's political outlook has changed while the Goffmans were settling down in isolated Mannville, inhabited by two hundred people. 
In 1919, while in Russia a civil war was still raging, in Winnipeg, where the maternal side of the Goffman new family was, a general strike lasting several days was ended by police gunfire. Its last day was soon called "Bloody Saturday", and those years are still remembered as the "red scare".

Erving was born in 1922 in Mannville, but just a few years afterwards the Goffmans moved to Dauphin, which is about 200 miles from Winnipeg, where in 1926 they opened a clothing and household goods store. They were better able to survive economically, and even to thrive eventually, in Dauphin. They also regularly received visits from their relatives living in Winnipeg. According to his colleague and friend Dell Hymes, while the two of them were talking about bilingualism Goffman reminded him that he grew up speaking Yiddish, "in a town where to speak another language was to be suspect of being a homosexual" (Hymes, 1984). Having the British Empire as his political horizon, Goffman had to get serious about studying the English language.

After more than a decade spent in Dauphin, a city much larger than Mannville but still offering very limited opportunity of social life to Jews, having reached a much better economic situation the family moved back to Winnipeg. From there Ann and Max had possibly escaped twenty years before, with their greater hopes, including in all likelihood a quite understandable desire to avoid being secluded in the Jewish ghetto. Ann and Max returned to Winnipeg to help Frances, who was pursuing an acting career, and to allow Erving to earn a high school degree. Those years apparently he spent often alone reading, listening to music, and probably to the radio. He developed an interest in chemistry, the discipline he first pursued when he enrolled in college. Both sets of skills may help explain the way he later worked on social science issues, bringing to them a well developed knowledge of English literature, and also a familiarity with the scientific method as it is applied in chemistry, rather than in a different domain like mathematics or physics. The kind of social life he lived lends itself to be interpreted as conducive to his sociological view, focused on face to face interactions, non verbal language, and small gatherings.

Strong "nativism" and "antisemitism" sentiments were certainly a problem for the Goffmans in Canada. While a comparison with European or American varieties of these sentiments is not in order here, as Cavan pointed out their social position was that of "outsiders", with respect to mainstream anglo-saxon society (Cavan, 2014). However, as Cavan possibly downplays, they were "outsiders", to some extent, also with respect to Winnipeg's Jewish ghetto life, especially when it comes to Erving, who moved there only as a teenager.

To this day, this set of circumstances can explain to some extent our lack of information about Goffman's diverse cultural background, and his difficulties in sharing his life story when he later moved to the United States, where people were not necessarily ready to understand it, even if willing. This background sheds some light on Goffman's work, starting from his first book, The Presentation of Self in Everyday Life, obviously dedicated to the intricacies of social acceptance "mechanisms", and its success well beyond the realm of academic sociology.

But a sociological explanation must also take into account how others saw him, and described his behavior. The limited objective of the remaining of this paper is to make a small contribution to the several decades old, and since a long time ago unmanageably large body of literature dedicated to Goffman's work, by addressing a 
particular aspect of the problem of explaining how Goffman became the celebrated, but also neglected, "Goffman" he is today: namely, the issue of Goffman's allegedly "enigmatic" personality and writings (Lemert, 2003).

\section{Berger's Puzzled Interpretation of Goffman's “Drive and Temperament"}

Bennet Berger offered a puzzled interpretation of Goffman's work and personality in his Introduction, added to the 1986 reprint of Frame Analysis (Goffman, 1974), which Berger defined as Goffman's "most systematic work". Even though clearly appreciative and supportive, Berger seems to complain that Goffman's "brilliant excursions often end with a shrug", as if he were saying "I don't particularly like it, but that's the way it is". In other words, Berger seems dismayed by the fact that such a brilliant analyst ends up by arguing that not much can be done about the way things are in the social world, even when that's clearly not to his own liking.

Frame Analysis. An Essay on the Organization of Experience (1974) is, as Berger describes it, "an effort to fulfill his aim, stated a few years earlier, to transform the study of interaction from a grab bag of empirical illustrations for other fields of sociology into a theoretical field in its own right" (Berger, 1986, in Goffman, 1986/1974:viii). In 1982, by choosing The Interaction Order as the title of his presidential address to the American Sociological Association (Goffman, 1983), Goffman implicitly suggested that his aim had been stated not "a few"-like Berger writes referring to Interaction Ritual (Goffman, 1967)—but thirty years before. It was in 1953, for the title of last paragraphs of his Ph.D. dissertation, that Goffman spoke for the first time of The Interaction Order.

In his A Fan Letter about Goffman (1973), Berger had already written much of what he later presented as his Introduction (1986) to Goffman's Frame Analysis. The issues Goffman deals with, he wrote in 1973, "in his most recent book, Relations in Public (1971), are the ones he has always dealt with, the stuff of elementary sociology: the fundamental units of social structure, selves, norms, roles, interaction between face-to-face individuals, the rules of 'co-mingling' in public places". This was so plain to anyone who read his writings that, Berger reports, "I have seen people become fidgety when Goffman walks into a room, suddenly self-conscious that their apparently effortless sociability might reveal something unintentional".

Berger points out that "his preoccupations are with what anyone can see, but usually doesn't, unless he looks carefully and with fresh eyes", as we have seen, and he also points out that Goffman is "of course, in the company of some others who call themselves ethnomethodologists or phenomenologists, or existential sociologists".

What happened from 1949 to 1953 was that as a doctoral student Goffman was supposed to describe the social "structure" of an island community. But what he wanted to do instead, or what he did do, anyways, was to begin his work of a lifetime: i.e., conceiving and deploying a new "conceptual scheme" for the study of social life, later called, also, "microanalyses", focused on "face to face" interactions. 
As a Canadian-born, Eastern European or Russian Jew pursuing a scholarly career in the United States of America of the 1950s, he was undoubtedly experiencing barriers to social acceptance. Whether or not this fact may explain his choice of doing the work on the island his own way, of course, is open to discussion.

In any case, shortly after becoming a professor of sociology of the University of California at Berkeley, in 1958, he "rocked the boat" of academic sociology by becoming also a best-selling author. Starting with his book The Presentation of Self in Everyday Life (Goffman, 1959), and quickly following up with more and even more unconventional books, he became a "problem" for many of his colleagues.

As Berger wrote, in both texts of 1973 and 1986, "more stories are told (and repeated) about encounters with Erving Goffman by those who knew him than about any other sociologist I can think of". And he tries to make sense of both Goffman's writings and the several "Goffman's stories" which seem to contradict them, as far as his personality is concerned.

On one hand, forgetting about the "I don't particularly like it" feeling that Goffman's analytical work left in him, Berger says that "he was driven by the sense that social order itself was a fragile and precious achievement". On the other hand, Berger says about the lively behavior of Goffman, "it is true that he was also a rule-breaker, a framebreaker by temperament; there was a bad-boy outrageousness in him that delighted in testing rules by testing the limits of tolerance toward the braking of them" (Introduction to Goffman, 1986/1974:xvii).

Berger seems to be complaining at first about the "shrug" of indifference, as if Goffman's "brilliant excursions" should be ending in his view either with a strong approval, or disapproval, of the way things are found to be-and with a call to action. Then, based on the "Goffman stories" he reports about, he sees him as not the kind of person you could anticipate what he would write, say, or do-except, of course, "testing the limits" of your ability to tolerate his "bad-boy outrageousness".

All of which made him a valuable scholar but an undesirable colleague, for professional sociologists-both because of his too dispassionate scholarship, and because of his too passionate personality. Apparently, Goffman was getting too much fun from both theorizing about the interaction order and from practicing the disruption of it, at least with his colleagues, whenever he had a chance.

One way to look at Berger's account is that to imagine Goffman wanted to take other's attention away from his own stigmatized attributes (Goffman, 1963). Disrupting the interaction order implied challenging his colleagues' self-comforting professional self-images, and what has to be considered, in order to explain Berger's puzzled attempts at figuring out Goffman, is that he finds it "unthinkable to imagine him contributing money to a 'conservative' political cause".

In other words, Berger is defending Goffman from those who accuse him of being a "conservative" sociologist (Gouldner, 1970), or, since Goffman himself admits that his work may be considered "conservative" in some sense (he is not trying to "wake up people to their real interests"), Berger argues that "conventional political terms" should not be applied to him, because of his "almost systematic ambivalence".

Goffman's actual position is not well reflected by Berger's puzzled comment about his supposed "ambivalence". His call for an "unfettered and sponsored" sociology (Goffman, 1983) offers the key to follow the consistency of his lifetime work-of 
course, to be followed as a "work in progress", and not to be confused with a lifelong striving toward an impossibly predetermined "goal" (Goffman, 1981).

Choosing his presidential address to the American Sociological Association (ASA) as a reference point, one must take notice that in this 1982 essay he made reference to the legacy of sociology, which he called "our inheritance", as a whole, and identified the social function of all sociological work-not just his own work ${ }^{39}$ -, as the "unsponsored analyses of the social arrangements enjoyed by those with institutional authority-priests, psychiatrists, school teachers, police, generals, government leaders, parents, males, whites, nationals, media operators, and all the other well-placed persons who are in a position to give official imprint to versions of reality" (Goffman, 1983). While in 1973 Berger had not yet had a chance to read it, by 1986 he had but, apparently, he did not.

Berger decided, in any case, either not to take these words into any consideration, or to consider them another example of Goffman's "almost systematic ambivalence". The latter view is hardly sustainable without putting forward the criteria by which the supposed "ambivalence" is to be determined, regardless of "conventional political terms". Berger splits then Goffman's way of thinking in two: 1) a "Nietzschean moral adventurer", fascinated by the "courage" of those who put their own "sense of self at risk", together with the "micro-order on which it depends", and 2) a "prudent Victorian", "deeply impressed by the power of ceremonies", to rule even out intimate lives and "keep the savage at bay". But Berger is not able to support this summary with any reference to Goffman's texts. He seems to rely merely on his personal acquaintance with Goffman, whatever that consisted of.

Goffman is interested in what breaking the rules may reveal about what the rules are, not about the rule-braker's "courage". In his world "the savage" does not exist. ${ }^{40}$

Another way to look at the "Goffman stories", from Goffman's point of view, is to imagine that he wanted to raise his colleagues' level of attention about the dynamics of the "interaction order". ${ }^{41}$ Their possible outrage was a necessary price to pay in order to show them the reality of the "interaction order", and to legitimize his own status as a "sociologist" — which depended at least in part on them recognizing it as a legitimate concern. Or, as he argues, a legitimate domain of sociological inquiry.

\footnotetext{
39 Rosenberg recently put it this way: "Erving Goffman's posthumously published essay, 'The interaction order', which was to have been presented as a presidential address at an annual meeting of the American Sociological Association, is usually taken to be an attempt at a systematic summary by Goffman of his key ideas", overlooking the fact that it was also a "critique of mainstream sociology" (Rosenberg, 2020).

40 His interest in "situational improprieties" is motivated by what they reveal about social rules, not "mental illness" or personality traits in general. About human nature, he finds it "everywhere the same" (Goffman, 1955), and Goffman does not express any admiration for "ceremonies and rituals", either "Victorian" or "anglo-saxon middle-class".

41 As it is well understood, for example, by the author of his obituary published on ASA's website.
} 


\section{Lemert's "Goffman's Enigma"}

Two decades after his death, "Goffman continues to breathe fresh air into creative scholarly works", argued Charles Lemert in his preface entitled Goffman's Enigma (Trevino, 2003:vii), "precisely because his writings always, almost without exception, were in their way enigmatic". Lemert could have argued that Goffman's writings "are" in their way enigmatic, instead of saying that they "were" so, which by placing them in the past may sound like an implicit suggestion to forget about them. However, the difference he brings in between enigmatic and "in their way" enigmatic writings is introduced by a dictionary definition of the word "enigma". It means, as Lemert reports, "a short composition in prose or verse, in which something is described by intentionally obscure metaphors, in order to afford an exercise for the intelligence of the reader or hearer in guessing what is meant: a riddle" (Oxford Dictionary, quoted by Lemert, 2003). ${ }^{42}$

To be talking about "intentionally obscure metaphors" sounds like a straightforward indictment. On the contrary, Lemert claims to be appreciative of the fact that Goffman is affording "intelligent" readers with useful "exercise" opportunities. But then, he bluntly states that Goffman "uttered barely a word that can be taken with final seriousness" about "the argument of structures and individuals", and this statement does read like an excommunication-or as a warning not to take him "seriously".

The supporting evidence used by Lemert is an anecdote, involving a British philosopher, who allegedly met "the great but inscrutable American sociologist" at a formal dinner. The philosopher was allegedly puzzled by Goffman's engagement in a prolonged conversation about second-hand clothes with the philosopher's own young daughter. From this anecdote, which Lemert regards as a typical example of the "Goffman stories" already put to work as we have seen by Berger (Berger, 1986), he moves to the written legacy by taking Goffman's presidential address to the American Sociological Association (Goffman, 1983), which in his view is the "best example" of his enigmatic persona.

Goffman "claims to have intended" the address "only as a talk", but, Lemert argues, he "had to have known very well that, whatever he intended, these addresses are always published by the American Sociological Review". Goffman was "therefore obscuring the truth of his intentions, in order to invite a question". One is led to think that Goffman's address does not mention the tradition of publishing the address itself on the ASR, counting on the reader not to know about it. He "had to have known very well", Lemert says, which implies that Goffman pretended he did not know about it. However, as we have seen Goffman opens his address precisely by describing this rule and by arguing that "a presidential address faces one set of requirements, an article in a scholarly journal quite another". He writes that "it turns out, then, that ASR's policy of publishing each year's ASA address provides the editor with an annual breather". He describes it as a matter of editorial policy, not of

\footnotetext{
42 As usual dictionary definitions are not of great help. Should we take into consideration a dictionary definition of the term "riddle" we would find ourselves, sooner or later, back to the term "enigma".
} 
the association's statutes and bylaws. And he explains what he means by the metaphor (an "annual breather") by listing the requirements of scholarly paper.

Lemert praises the address as one of Goffman's "finest", and "funniest", papers, so one may assume that he must have read it carefully, and also compared it to other examples of Goffman's scholarly production. What has not to be taken literally (that "he had to have known"), but instead figured out here as an "enigmatic" hint is what Lemert wrote-not what Goffman wrote. As Lemert claims, Goffman reveals in his address that he was thinking about "considering it as a talk and not publishing it", before he knew he was not going to be able to deliver it in person. How does that amount to "obscuring the truth of his intentions" remains unclear. One may express his past desire to break a rule, while reporting that he decided not to do it and why, which is what Goffman did. He could have given the speech and then refuse to submit the manuscript - as he did on another occasion, less important but nonetheless similar (Winnipeg Free Press, 1976). However, such a behavior would have surely raised a controversy, and what Lemert seems to be arguing here is that this was never going to happen. He assures us that Goffman never really thought of doing anything as "bad boy outrageous" (Berger, 1986) as that.

Goffman is supposed to have used an empty threat, thrown at his readers after the point in time in which it could have been understood as a real threat, in order to draw everyone's attention to something else, which Lemert identifies as the "emptiness of meaning and importance of all ceremonies centered around presidential addresses". However, the latter is a point that Goffman focuses on in the address, and has important implications for his theory. As much as his intention was to draw everyone's attention to this topic, it was not "obscured"-and it may by itself even confirm the story just as Goffman told it. By Lemert's account, Goffman misled his readers about his "true" intentions, but when he reveals what they are, it turns out that his allegation is untrue-because Goffman himself expressed those intentions in his paper.

Lemert then assures us that the address would have been "well received", if Goffman had delivered it in person. He seems to be adding to the story here by implicitly suggesting that Goffman was not sure about the reception of his own presidential address, and thereby did not want it to be published. ${ }^{43}$

Lemert casts Goffman as someone who both in his writings and in his lively behaviors pretends he does not know, even when he obviously does know, about a social rule. Writing a presidential address is supposed to be for "Goffman" just like talking to a girl about second hand clothes while pretending to ignore that one is instead supposed to engage in a philosophical discussion with her father. Obviously, the philosopher was placed next to him at the dinner for a reason, but Goffman allegedly ignores him, in order to expose the embarrassing fact that neither of the two are really interested in the polite exchange of views that is supposed to take place at the

\footnotetext{
43 Anyone can make up their mind about such an allegation after reading anything Goffman wrote. It's hard to imagine, however, that Goffman was ever intimidated by his colleagues' possible rejection of his work.
} 
dinner-and that, nonetheless, is supposed to have taken place, thereby enhancing the prestige of the organization which paid for it.

Lemert's characterization may be accurate with respect to Goffman's social behavior as it is described by the anecdotes showing him engaged in so-called "breaching experiments"-sociological "experiments" which were popular at the time, as Berger pointed out (Berger, 1973), ${ }^{44}$ but when it comes to his writing Goffman describes and criticizes the social rule, whether his threat of breaking it was ever "real" or not. The British philosopher may be to some extent forgiven for not understanding Goffman's behavior, if he really did not, bur Lemert has no excuses. The riddle according to which Goffman "had to have known very well", and was hiding his "true intentions", is entirely of Lemert's own device. Based on the confusion of writings and anecdotes, he casts all of Goffman's work as "enigmatic", and not to be taken seriously.

Lemert's essay includes other references to Goffman's work, and some of them seem to be appreciative. However, keeping in mind that he had already claimed Goffman "uttered barely a word that can be taken with final seriousness", about "(social) structures and individuals", one can be sure that his assessment can be appreciative only up to a quite limited extent. Lemert seems to agree when, summarizing Goffman's views, he claims that "we are what we are in spite of the structured pressures, but the only way we can be in our situations is by breaking the rules the authorities impose". ${ }^{45}$ In Goffman's presidential address, one instead finds that "the workings of the interaction order can easily be viewed as the consequences of systems of enabling conventions, in the sense of the ground rules for a game, the provisions of a traffic code or the rules of syntax of a language". It would be odd to argue that we can "be" ourselves "only" by breaking such rules. For example, by crashing our car on someone else's, or by uttering randomized sequences of words. Clearly, Lemert's account is not as accurate as it should be here.

Goffman's view on this crucial point of social theory is that, contrary to simplistic interpretations and mainstream assumptions_-and he explicitly addresses his criticism to both the "utilitarian" (or "social contract") and the "consensus" (or "core values") views -, "one cannot read", from the "apparent tacit support of an arrangement", that people would "resent or resist its change". Conversely, as he points out, the other side of the coin is that "individuals who systematically violate the norms of the interaction order may nonetheless be dependent on them most of the time, including some of the time during which they are actively engaged in violations" (Goffman, 1983:5). These concepts he had already put forward much earlier, for

\footnotetext{
44 "Ethnomethodological breaching experiments" consist of breaking a taken for granted social rule in order to assess how people react to it, which will depend on how much importance they give to that rule and on their self-awareness with respect to that particular social rule and how it applies.

45 However, one may think that if we are what we are "in spite" of the "structured pressures", of course we will only "be" ourselves by breaking the rules the authority impose. There is no reason to insert the word "but" in Lemert's statement, unless, in Lemert's view, "structured pressures" and "rules the authority imposes" are not the same thing. But if they are not the same thing, it becomes hard to think about these "pressures", which, supposedly, do not make us who we are. Once again, the obscurity seems to be on Lemert's account.
} 
example in his Relations in Public: Microstudies of The Public Order (1971) where he also argues, right at the beginning, that clothing (which is a legitimate topic for sociologists, and for philosophers also, one would think) as a sign of respect belongs to the "scene", a term by which Goffman quite understandably means the place where people meet, whereas turn-taking belongs to the "encounter", by which he means the process of exchanging views. These are plainly understandable, hardly "enigmatic" concepts aimed at describing some of the "enabling conventions" that are usually largely taken for granted-and aimed at having them being verified. Even though metaphors, like "scene", for the place where an encounter takes place, are introduced - and even if a "riddle" may be found at times, in Goffman's writings, what he says here is clear. Within the "territories of the self", Goffman includes the "sheath", for one's natural skin and for one's clothing, noting that "among the American middle-class, for example, little effort is made to keep the elbow inviolate, whereas orifice areas are of concern". Given that "across different cultures the body will be differently segmented ritually", this "differential concern tells us in part how the body will be divided up into segments conceptually" (1971:38), thereby establishing rules, or "rituals", that will be more or less compatible with other rules, or "concepts", concerning social settings and social interactions.

Probably, Goffman's conversation with the philosopher's daughter was not far from the related topics of the "sheath" and the "scene", which are the source of potentially endless conversations involving the issue of social acceptance. If they had talked about "concepts, rules, or rituals" in an abstract manner, of course, the philosopher would have felt involved and would not have complained afterwards. But the daughter, on the other hand, might have quit her involvement in the conversation.

At the end of the day, Lemert assures us that "Goffman the man, and the works of his pen, were nothing if not that"; i.e., "enigmatic". A solution to the "riddle" is found by him in the fact that, surprisingly, it "does not have a solution". Supposedly, "such is the social reality to which Goffman invites us from the other side of the grave-wherever that might be". That's, however, his (Lemert's) enigmatic conclusion.

Without offering an alternative to Goffman's views, Lemert also wrote that "such is life"-implying that "enigmatic", for him, is not just the "social reality to which Goffman invites us", but that all living organisms are by definition "enigmatic". Which, of course, makes it pointless to label anyone as an "enigmatic" writer, or individual.

In his presidential address, Goffman wrote that "my expectation was" to treat it as a talk, "but in fact, I wasn't there either". ${ }^{46}$ Whether he would have actually broken the "ASA-ASR tradition", if he had the chance to, no one can really say. Lemert may be right in arguing that he would not have done it but no one, possibly not even Goffman, can say what would have happened if he had not contracted a deadly illness at that point in his life.

However, this "riddle" might have interesting aspects to it. The founding of the "American Sociological Review", in 1935, was a "rebellion against the

${ }^{46}$ By the word "either" the talk is given a sort of "participant" status to the ceremony. 
influence of the Chicago school on the profession", by the professional association of American Sociologists. What were the "sources" of this rebellion was still debated at the time Goffman gave his address, and Patricia Madoo Lengerman had published a study on this topic, in the ASR, just a few years before Goffman's presidential address (Lengerman, 1979). Lemert's riddle, about "Goffman's riddle", may boil down to this turning point in the history of American sociology, even though neither of the two ever wrote about it explicitly. Goffman probably meant to expose the fact that he would not have been allowed to disregard that unwritten rule, or "editorial policy", even though he was ASA's elected President. Possibly, this was also a reminder that he represented, in some way, a "revenge" of the fieldwork oriented sociology still practiced in Chicago when he arrived there. His "expectation", as he calls it, was not going to be given the slightest amount of consideration, he points out implicitly, thereby ironically placing his colleagues in the embarrassing position of either being themselves "deviants", or of calling their president out as a "deviant". Which is precisely the attitude Lemert shows two decades later, in an unwarrantedly dismissive fashion. Lemert argued that Goffman's work was still being discussed "precisely" because his writings were "in their way" enigmatic. By this term-"enigmatic"-he meant that Goffman is leading us nowhere. But his claim is not supported by the evidence he submitted. Goffman is actually leading us toward the "center" of American sociology, as he sees it.

\section{Conclusion: How A Stranger Responds to The Native's Moral Alchemy}

Whether positive or negative, criticism has to be grounded on its object which has to be, at the end of the day, what Goffman actually wrote. ${ }^{47}$ By itself, what he wrote is a large and dense body of literature. Unfortunately, and at times surprisingly, it is quite easy to find examples of inaccurate readings of it, at times based on hearsay concerning his "personality" which obscure the content of his writings. As Shalin pointed out, "we need to bear in mind that biocritical accounts may reveal as much about the biocritic as about the object of biocritical investigation" (Shalin, 2008:11).

Goffman's trajectory can be located within the larger theme of "sociologists as outsiders". Some clarification of this issue comes from Simmel's treatment of "the stranger", and from Merton's notion or "moral alchemy"-according to which outsiders are "damned if they do and damned if they don't exhibit group virtues" (Merton, 1957:430), while "with a fine sense of moral superiority, the secure in-groups looks at this curious performances by the outgroups with mingled derision and contempt" (Merton, 1957:434).

Fine and Hallet (2014) summarize Simmel's notion of the "stranger" (1950:402), by reporting that "a stranger can be simultaneously near and far: "the person who comes today and stays tomorrow', and who", they add, "is recognized for doing

\footnotetext{
47 One thing most careful critics have pointed out is that Goffman's writings do not fall under any of the labels that were applied to them, which ultimately, as he pointed out, calls into question the meaning of those labels (Goffman, 1981; Verhoeven, 1993).
} 
so" ${ }^{48}$ They point out that "the stranger is a dramatic role that some play, illuminating social boundaries, but it is also a position that we depend on to ensure that we are not swept away in a tide of conventional meaning. Ethnographic insight depends on this standpoint". Goffman can be then seen, from this point of view, as "a stranger at the center of an academic discipline", who adopted that standpoint - that of the stranger-as a means of generating insights. That of "the stranger" is a social relationship in which he entered, and remained, however, by definition not entirely of his own will. He probably tried to take advantage of Simmel's insights about the "impersonality" of the stranger: he took advantage of the opportunity to be "objective" (or impartial, and be seen like that by others), and he fought against the risk of being "objectified" (treated as a non-person, a nobody, merely another annoying Jew).

As Simmel and Goffman would have predicted, however, Goffman's name is tied both to empty celebrations, and actual neglect of his work. Simmel himself was kept at the margins of the academic world in Germany, while in America he found his audience, including Goffman's careful study of his work. Goffman did not want to end up marginalized like Simmel (Berger, 1986) or like Veblen (Shalin, 2013), and he clearly did not, as he reached the Presidency of ASA. However, it is also important to take into consideration the distance which is still maintained towards him and his work, even by some of the sociologists who are apparently more engaged in closing the gap.

Goffman's "sociological imagination" is possibly more akin to Garfinkel's than to C.W. Mill's (1959) formula (the intersection of "biography and history"). He quotes Garfinkel at least since 1953, and from an "unpublished paper". In Stigma, he gives him credit for his concept of "biography", and no doubt there are similarities between the two. However, Goffman also parts ways at the theoretical and methodological level with Garfinkel, arguing that a distinction should be maintained between "situational" and "situated" elements of a social interaction (Goffman, 1983). ${ }^{49}$ Goffman's words about Garfinkel are also that "here indeed the writers in the tradition I am following" (meaning James, Schutz, and Garfinkel) "have quietly

\footnotetext{
${ }^{48}$ Simmel's definition already included "recognition" by others. What Simmel wrote, a few lines below the above mentioned hurried quotation (all social relationships for Simmel include a mixture of near and far, "a unity of nearness and remoteness", he says, is "involved in every human relation "), is that "the stranger, like the poor and like sundry 'inner enemies', is an element of the group itself. His position as a full-fledged member involves both being outside it and confronting it".

${ }^{49}$ In his interview to Verhoeven (published in 1993), he argues that the term "ethnomethodology" and the now alleged "three sociological perspectives" ("symbolic interactionism, conflict sociology, and structural-functionalism") do not have any relationship with actual social research, or any actual precise meaning at all (unless as vague proxies for "Garfinkel", "Marx", "Radcliffe-Brown", etc.). I agree with Goffman here. Every social thinker, Comte included, recognized that cultural differences are key to any understanding of the problems any social arrangement faced and solved. Merton pointed out that describing "religion" as functional to the survival of the group, or as a form of oppression within the group, is a matter of values ("it is in the evaluation of these functions of religion, rather than in the logic of analysis", that "the functionalists and the Marxists part company" (Merton, 1949, 1957: 45). One function does not exclude the other, and it is also a question of empirical findings, however. Only if one "imagines" a society without any internal hierarchy, then its "religion" will have to be useful to that society as a whole—or, eventually, die out.
} 
fallen down. To speak here of 'everyday life', or, as Schutz does (...), is merely to take a shot in the dark" (Goffman, 1974: 26). Berger does not mention at all this critique in his Introduction to Goffman's Frame Analysis (1974)—which was written in 1985, but largely based on his 1973 article A Fan Letter on Erving Goffman, where he portrayed him as akin to "ethnomethodologists" and others, based on his "badboy" behavior, as we have seen. ${ }^{50}$

Certainly, a number of other significant theorists in sociology have been characterized as loners, or solitary, or nonconformists. However, the alleged "abrasive" personality of C.W. Mills, for example, was never invoked to support the argument that according to Mills all human beings are naturally "abrasive". On the contrary, Berger and Lemert support their interpretations of Goffman's understanding of human "wild" nature, and "constrained" social behavior, with their own interpretations of Goffman's behavior. ${ }^{51}$ Goffman behaved in his own ways and ultimately decided to be secretive about his private life for several reasons. However, once properly treated Goffman's ideas constitute a significant legacy building on classic sociology and many other sources of knowledge, bearing on all current issues. It should not be obscured by hearsay, however entertaining or upsetting they may be, or "Goffman stories", that were certainly in part a result of the method he used to demonstrate his sociology, including his position about the problem of "mental illness", and on the other hand also in part a response, by his American colleagues, to his social position of a "stranger" in the United States' academic environment-and a very successful one, both academically and as a popular writer.

To understand in "generational" terms the mixture of celebration and neglect in which we find Goffman, thanks to the "Baby Boomers", "engaged" generation of American sociologists, ${ }^{52}$ it may be useful to go back before the Second World

\footnotetext{
50 Jaworski recently argued that Goffman was "no phenomenologist", based on (Psathas, 2014) which is apparently focused only on Goffman's critique of Schutz. But Psathas argument is based on the same 1974 text I just quoted, where Goffman criticizes a plurality of "writers" (James, Schutz, and Garfinkel). According to Jaworski, even though he was "no phenomenologist", Goffman's "inner affinity" with Simmel "reveals, also, an affinity with Schutz" (Jaworski, 2020). Goffman himself placed Schutz within "the tradition I am following" and then criticizes the whole "tradition", including Schutz, claiming that "everyday life" must be broken down into several frameworks and their combinations.

51 Manning and Gouldner, respectively, claim that according to Goffman humans are "selfish"-even though less so in 1959 than in 1956, according to Manning (Manning, 1991) -, and believers in "appearances" only, according to Gouldner (Gouldner, 1970), but their claims are at least allegedly based on the way they read his writings, and not on Goffman's alleged "personality".

52 In 1939, Goffman was seventeen and the Second World War began, with a staged "invasion" of Germany by German soldiers, disguised as Polish soldiers. At this point in one's life important choices are made concerning one's values, as Mannheim pointed out, and the life of "generations" is also involved here (Mannheim, 1952). Generational choices are related to major social events like that war, which began-like many others - with a fraudulent act perpetrated by a powerful head of State, certainly was. It's probably hard to overestimate how the war marked a turning point in Goffman's life, including what he soon must have learned about the "Shoah", and then about the two nuclear bombs dropped by the U.S. on Japan. Of course, the Cold War between allegedly "democratic" and "socialist" worlds will be kept up throughout his whole life. However, an important development happening close to Lemert's seventeenth birthday is that after the death of Stalin, in 1953, the Soviet Union started releasing political prisoners and deportees from its Gulag prison camps. At this point in time Goffman, a thirty-one year old, decides to write about the "interaction order" at the end of his dissertation.
} 
War, when in his Preface to the American edition of Karl Mannheim's Ideology and Utopia, Louis Wirth complained that it was "virtually impossible, even in England and America, to inquire into the actual facts regarding communism, no matter how disinterestedly, without running the risk of being labelled a communist" (Wirth, 1936:xvii). Goffman took pride in remembering having followed Wirth's lectures in Chicago, in the late 1940s. But he begged to have given himself a "disgraceful" answer, as Wirth would have considered it, to the question of why sociologists should study society.

For Goffman, it's enough to say that society "is there", whatever the sociologist would like it to be, or not like it to be. Despite Wirth's above mentioned commitment to a "disinterested" inquiry, a disagreement between the two emerged, possibly during one of Wirth's lectures. To become aware of one's own biases, as Wirth suggested to social scientists, by "the tracing of the bases of social judgement to their specific interest-bound roots in society", does not for Goffman, as it does for Wirth, "make possible at least a working agreement on what the facts in an issue are" (Wirth, 1936:xxviii). For Goffman, a working agreement is not "made" possible by such an inquiry into a social scientist's "interest-bound roots in society", because it is already possible to begin with. It is precisely the substance of everyday social life. This "substance", metaphorically speaking, Goffman breaks down into "elements", or, as he says at the beginning of his inquiry, "particles of behavior", such as those we use to give life to the interaction order: a facial expression, a gesture, bodily signals of engagement in the conversation, an appeal to shared values, including that of "science", and to social norms appropriate to the situation, including the social identities of its participants (Goffman, 1951).

This "microsociological", if you will, point of view was far from being unheard of in the history of sociology, quite the opposite. Given that sociologists are members of a society, they will always be biased, and to some extent they will know it. They will always have some level of awareness of their own biases, which is what is at stake here. But if the "tracing" of one's own interest in a social issue, or matter of investigation, and the tracing of one's own goals within the social structure, in its historical development, had to be the "precondition" of any working agreement in the social sciences, as Wirth claimed (Wirth, 1936:xxviii), Goffman's rebuttal seems to have been that no such working agreement would even be possible. If such a "precondition" had to be fulfilled in advance of any "working agreement", in other words, there would be none. Not much awareness can ever be gained this way, then, but this is exactly the path American sociology has taken, according to Goffman, during his lifetime. Goffman makes reference to the sociological mainstream, at the end of his life, by saying this: "we all agree, I think, that our job is to study society. If you ask why and to what end, I would answer: because it is there. Louis Wirth, whose courses I took, would have found that answer a disgrace. He had a different one, and since his time his answer has become the standard one" (Goffman, 1983:17). In his Presidential Address to ASA, delivered in 1947, Wirth called sociologists to the urgent task of "understanding the process through which consensus on a world scale is created". Given the clear and present danger of a nuclear war, sociologists must focus, according to Wirth, on the "effective use" of the "mass media of communication", which 
"are capable of providing the picture of social reality and the symbolic framework of thought and fantasy and the incentives for human action on an enormous scale" (Wirth, 1948). Consistently with this agenda, the following year Wirth became the first President of the International Sociological Association (ISA), whose mission statement was centered around a "human rights" provision-a position which, on the other hand, was never added to ASA's mission statement. Not surprisingly, fifty years later ISA was still "only very imperfectly international" (Wallerstein, 1998:9). However, in the meantime, the "human rights" agenda had "backfired", making the issue a prominent one at home.

From the sociologist's point of view, the problem of credibility, or embarrassment, belongs to social relationships, and Goffman does not shy away from taking into consideration the political issue arising here. In his Frame Analysis (1974) he explains that according to the "official definition of reality" the golf player is playing a game, while the caddy, on the other hand, is actually working, as may be a golf instructor. Both workers will likely be ready to acknowledge that they are "servicing persons engaged in play" (1974:8), says Goffman, but he acknowledges that he is describing the situation in his own way, "arbitrarily". What he can do is only try to make sure that his description is "easily recognizable" by all those who are involved. Here is how Goffman put it: "I will initially assume the right to pick my point of view, my motivational relevancies, only limiting my choice of perspective to one that participants would easily recognize to be valid" (1974:9). Arguably, being born closer to the side of the caddy rather than to the side of the golf player will endow a sociologist with her own personal sensitivity — which we may boil down to the need to understand all the people one is talking about, and make oneself understood by all of them, notwithstanding their different "perspectives" and what the "official reality" in which they live is. Any sociologist will to some extent show a personal sensitivity to the social issues she is involved with, which will be different from that of other sociologists - relatively, for example, to "generational" issues (Mannheim, 1952).

What Goffman was interested in was improving sociology regardless of any commitment to help the "free world" win its war, or "peaceful" competition, against the "socialist world", or to help anyone else, for that matter, win any particular war. His relationship with many of his colleagues was quite difficult, as a result, and his legacy is often misunderstood even today, in part for this reason. His lack of commitment to the cause of so-called Western Civilization did not help him. Nor did help him focus on what he saw as the major shortcoming of mainstream sociology: i.e., its neglect of what he called the "interaction order". Such shortcoming had already been exposed by many, including the founders of the so-called "Chicago School" which, as Coser pointed out in his Masters of Sociological Thought (1976), was not lacking theoretical depth, controversies, and reciprocal overlooking.

Such shortcoming, however, was identified and systematically addressed by Goffman, following hints from thinkers and scientists who not necessarily were all "sociologists". His original contributions were slowly being recognized as he produced them, and are still in the process of being fully recognized today. In order to do so, however, it is necessary to dismiss wrongful interpretations of his persona, work and context. 
Acknowledgements I am grateful for the encouraging criticism and the insightful suggestions I received from Larry Nichols and from two anonymous reviewers, which demanded from me and at the same time empowered me to improve this paper a great deal. Gary Jaworski was also very supportive when I presented a much earlier version of this paper at the New Voices in the History of Sociology Symposium (August, 11, 2020). I am also thankful for the advice I received later on about how to move forward both with my research priorities and with my writing style, by Taylor Winfield. Elijah Anderson kindly and openly answered my questions, both about Erving Goffman in his "flesh and bones" based on their friendship when they were colleagues at the University of Pennsylvania, and on all matters of interest to urban ethnographers, sociologists, and socially aware people in general. I am grateful also to Dmitri Shalin and Pier Paolo Giglioli, for their constructive answers to my questions, and, last but not least, to Felice Accame for his teachings in the "methodology of language".

\section{References}

Anderson, E. (2003). A Place on the Corner. The University of Chicago Press.

Becker, H. (1963). Outsiders: Studies in the sociology of deviance. Free Press Glencoe.

Berger, B. (1973). A Fan Letter on Erving Goffman. Dissent, 20, 353-361

Berger, B. (1986). Foreword to Goffman, E. (1974)

Berger, P.L., Luckman, T. (1966). The social construction of reality. A treatise in the sociology of knowledge.

Cavan, S. (2014). When Erving Goffman Was a Boy: The Formative Years of a Sociological Giant. Symbolic Interaction., 37, 41-70. https://doi.org/10.1002/symb.83

Collins, R. (1988). Theoretical sociology.

Collins, R., \& Makowsky, M. (1972). The Discovery of Society. Random House.

Collins, R. (2016) What Has MicroSociology Accomplished ? http://sociological-eye.blogspot.com/ 2016/04/what-has-micro-sociology-accomplished.html

Coser, L. (1976). Masters of Sociological Thought.

Fine, G. (2009). Goffman Turns to Me and Says, 'Only a Schmuck Studies His Own Life'. In Dmitri N. Shalin, Bios Sociologicus: The Erving Goffman Archives 1-14.EGA. https://digitalscholarship. unlv.edu/goffman_archives/20

Fine, G., \& Hallet, T. (2014). Stranger and Stranger: Creating Theory Through Ethnographic Distance and Authority. Journal of Organizational Ethnography, 3(2), 188-203

Fine, G. A., \& Manning, P. (2003). Erving Goffman. In: Ritzer, G. (Ed.), The Blackwell companion to major contemporary social theorists. Malden, Massachusetts Oxford: Blackwell.

Goffman, E. (1951). Symbols of Class Status. The British Journal of Sociology., 2, 294-304

Goffman, E. (1952). On Cooling the Mark Out. Some Aspects of Adaptation to Failure. Psychiatry: Journal of Interpersonal Relations. 15(4): 451-63.

Goffman, E. (1953). Communication Conduct in an Island Community. PhD Dissertation, Faculty of the Division, The University of Chicago.

Goffman, E. (1955). On face-work: an analysis of ritual elements in social interaction. Psychiatry: Journal for the Study of Interpersonal Processes, 18, 213-231.

Goffman, E. [1956] (1959). The presentation of self in everyday life.

Goffman, E. (1959). The Presentation of Self in Everyday Life. Anchor Books.

Goffman, E. (1961a). Asylums: Essays on the Social Situation of Mental Patients and Other Inmates. Doubleday Anchor.

Goffman, E. (1961b). Encounters. Two Studies in the Sociology of Interaction.

Goffman, E. (1963). Stigma: Notes on the Management of Spoiled Identity. PrenticeHall.

Goffman, E. (1964). The neglected situation. American Anthropologist, 66(6), 133-136.

Goffman, E. (1967). Interaction ritual: Essays on face-to-face behavior. New York: Doubleday Anchor.

Goffman, E. (1971). Relations in Public: Microstudies of the Public Order. Harper \& Row.

Goffman, E. (1974). Frame Analysis: An Essay on the Organization of Experience. Harper \& Row.

Goffman, E. (1981). A Reply to Denzin and Keller. Contemporary Sociology., 10(1), 60-68

Goffman, E. (1983). The Interaction Order: American Sociological Association, 1982 Presidential Address. American Sociological Review, 48(1), 1-17 
Gould, S.J. [1981] (1993). The mismeasure of man. New York, W. W. Norton and Toronto: GeorgeJ. McLeod Limited.

Gouldner, A. (1970), The Coming Crisis of Western Sociology.

Jaworski, G.D. (2020) Goffman, Schutz, and the 'Secret of the Other'. In Gregor Fitzi (Ed.) The Routledge International Handbook of Simmel Studies.

Hymes, D. (1984). On Erving Goffman. Theory and Society., 13(5), 621-631

Lengerman, P. (1979). The Founding of the American Sociological Review: The Anatomy of a Rebellion. American Sociological Review, 44(2), 185-198

Lemert C. (2003). Goffman's Enigma: Series Editor's Foreword. In Treviño, A. J.. Goffman's Legacy. Lanham, Md.: Rowman \& Littlefield.

Mannheim, K. (1952). Essays in the Sociology of Knowledge. Routledge and Keegan Paul.

Manning, P. (1991). Drama as life: the Significance of goffman's changing use of the theatrical metaphor. Sociological Theory, 9(1), 70-86.

Merton, R.K. [1949] (1957). Social theory and social structure.

Merton, R. K. (1957). Social Theory and Social Structure. The Free Press.

Mills, C. W. (1959). The Sociological Imagination. Oxford University Press.

Nedelmann, B., Sztompka, P., (1993). Sociology in Europe: In Search of Identity. Berlin, New York: Walter de Gruyter.

Orwell, G. (1949). Nineteen eighty-four: A Novel.

Park, R. E. (1950). Race and Culture. The Free Press.

Psathas, (2014). Goffman and schutz on multiple realities. In: Staudigl M., Berguno G. (Eds) Schutzian phenomenology and hermeneutic traditions. Contributions to Phenomenology, vol 68. Dordrecht: Springer.

Ritzer, G., (1993) The Mcdonaldization of Society.

Rosenberg M.M. (2020). Erving Goffman's presidential address on 'The interaction order': Rhetorical combat and the display of vocational commitment. Journal of Classical Sociology, 20(3), 208-224.

Sapolsky. R., (2017) Behave: The Biology of Humans at Our Best and Worst.

Shalin, D. (2013). Interfacing Biography, Theory and History: The Case of Erving Goffman. Symbolic Interaction, 37(1), 2-40

Simmel, G. (1950). The Sociology of Georg Simmel. Free Press.

Sulloway, F. (1996). Born to Rebel. Birth Order, Family Dynamics, and Creative Lives. NY: Pantheon Books.

Sutherland, E. (1940). White Collar Criminality. American Sociological Association, 1939 Presidential Address. American Sociological Review. 5 (1), 1-12.

Trevino, A.J. (2003). Goffman's legacy. Rowman \& Littlefield.

Verhoeven, J. (1993). An interview with Erving Goffman. Research on Language and Social Interaction, 26(3), 317-348.

Wallerstein, I. (1998). Introduction. To Platt, J. (1998) History of ISA 1948-1997. International Sociological Association. (https://www.isa-sociology.org/uploads/files/histoy-of-isa-1948-1997.pdf)

Weber, M. [1905] (1930). The Protestant Ethic and the Spirit of Capitalism. London: Unwin University Books.

Whitford, F. (1990). Klimt (World of Art). Thames \& Hudson.

Winfield, T.P. Rereading Durkheim in light of Jewish law: how a traditional rabbinic thought-model shapes his scholarship. Theor Soc 49, 563-595 (2020). Winkin, Y. (1988). Le Moments et Leurs Hommes. Paris: Minuit.

Winkin, Y. (1988). Erving Goffman: les moments et leurs hommes, Paris, Éditions du Seuil \& Éditions de Minuit.

Winnipeg Free Press. 1976. Aging Idiots' Gloomy World Forecast for Grads. Winnipeg Free Press, May 27, p. 83. (http://cdclv.unlv.edu/ega/news/agingidiots_76.pdf)

Wirth, L. (1936). Preface to Mannheim, K. (1936). Ideology and Utopia. New York: Harcourt, Brace and Company.

Wirth, L. (1948). Consensus and Mass Communications. American Sociological Association, 1946 Presidential Address. American Sociological Review. 13 (1), 1-15.

Publisher's Note Springer Nature remains neutral with regard to jurisdictional claims in published maps and institutional affiliations. 